Wibowo, et al/Jurnal Ekonomi Syariah Teori dan Terapan Vol. 6 No. 3 Maret 2019: 477-488; PENGARUH PEMBIAYAAN NON BAGI HASIL DAN FINANCING TO DEPOSIT RATIO (FDR) TERHADAP PROFITABILITAS PADA PT BANK MUAMALAT INDONESIA TAHUN 2012-2016

\title{
PENGARUH KOMPOSISI PEMBIAYAAN NON BAGI HASIL DAN FINANCING TO DEPOSIT RATIO (FDR)TERHADAP PROFITABILITAS PADA PT BANK MUAMALAT INDONESIA TAHUN 2012-20161
}

\author{
Renanda Rosita Wibowo \\ Departemen Ekonomi Syariah - Fakultas Ekonomi dan Bisnis - Universitas Airlangga \\ Email: renarossita@yahoo.com

\section{Dian Filianti} \\ Departemen Ekonomi Syariah - Fakultas Ekonomi dan Bisnis - Universitas Airlangga \\ Email: dian.filianti@gmail.com
}

\begin{abstract}
:
The purpose of this study is to analyze the relationship of non-profit sharing and FDR on the profitability of PT Bank Muamalat Indonesia. The approach used is quantitative, using multiple linear regression analysis techniques. The results of this study indicate that partially non-profit sharing is not significant to ROA, partially FDR has a significant negative effect on ROA, non-profit sharing and FDR simultaneously have significant effect on ROA of PT Bank Muamalat Indonesia.
\end{abstract}

Keywords: Non profit sharing, Financing to Deposit Ratio, Return On Assets, multiple linear regression

\section{PENDAHULUAN}

\section{LatarBelakang}

Menurut Sudarsono (2008:27), Bank adalah lembaga keuangan yang usaha pokoknya memberikan kredit dan jasajasa lain dalam lalu lintas pembayaran serta peredaran vang yang beroperas disesuaikan dengan prinsip-prinsip syariah. Sebagaimana bank konvensional, bank syariah merupakan sebuah entitas bisnis dimana perolehan laba merupakan tujuan utamanya (profit orientation).

$$
\text { Dalam perbankan syariah }
$$
terdapat dua jenis kontrak pembiayaan bila dibedakan dari sifat alami pengembalian atas kontrak-kontrak tersebut. Disinilah muncul istilah Natural Certainty Contracts atau pembiayaan non bagi hasil dan Natural Uncertainty Contracts atau pembiayaan bagi hasil.
Natural Certainty Contracts adalah kontrak atau akad bisnis yang mana terdapat kepastian pembayaran dalam jumlah dan waktu. Akad yang termasuk dalam Natural Certainty Contracts adalah jual-beli, sewa-menyewa dan upahmengupah. Sedangkan Natural Uncertainty Contracts adalah kontrak atau akad bisnis dimana tidak terdapa tkepastian pembayaran baik dalam jumlah maupun waktu (Hidayat, 2011 :51).

Dalam pembiayaan berbasis Natural Certainty Contracts, penjual memberitahukan terlebih dahulu harga perolehan kepada pembeli barang dan menyatakan jumlah keuntungannya yang ditambahkan pada biaya tersebut (Hidayah, 2013). Berdasarkan beberapa penjelasan tersebut, maka dalam penelitian ini akan difokuskan pada

\footnotetext{
${ }^{1}$ Jurnal ini merupakan bagian dari skripsi Renanda Rosita Wibowo, NIM: 041311433075, yang diuji pada tanggal 27 Juli 2018.
} 
Wibowo, et al/Jurnal Ekonomi Syariah Teori dan Terapan Vol. 6 No. 3 Maret 2019: 477-488; PENGARUH PEMBIAYAAN NON BAGI HASIL DAN FINANCING TO DEPOSIT RATIO (FDR) TERHADAP PROFITABILITAS PADA PT BANK MUAMALAT INDONESIA TAHUN 2012-2016

komposisi pembiayaan NCC (Natural Certainty Contracts). Hal ini dikarenakan dari data yang diperoleh berdasarkan Laporan Perkembangan Keuangan Syariah (LPKS) 2016 menunjukkan bahwa total pembiayaan NCC yang terdiri dari pembiayaan dengan akad murabahah, ijarah, salam dan istishna yang disalurkan oleh bank syariah beberapa tahun terakhir mempunyai presentase yang paling tinggi dibandingkan dengan pembiayaan NUC (Natural Uncertainty Contracts). Selain itu pada pembiayaan berbasis NCC terdapat kepastian pembiayaan baik dari jumlah maupun waktu (Hidayat, 2011:51).

Pembiayaan yang diberikan oleh bank kepada nasabah akan mendapatkan balas jasa berupa bagi hasil, margin keuntungan, dan pendapatan sewa, tergantung pada akad pembiayaan yang telah diperjanjikan antara bank syariah dan mitra usaha (nasabah). Pembiayaan akan berpengaruh pada peningkatan profitabilitas bank. Hal ini dapat tercermin pada perolehan laba. Dengan adanya peningkatan laba usaha bank akan menyebabkan kenaikan profitabilitas bank (Ismail, 2011:110).

Rasio pembiayaan Financing to Deposit Ratio (FDR) adalah seberapa besar dana pihak ketiga bank syariah dilepaskan untuk pembiayaan (Prastowo dan Rifka, 2010:148). Semakin tinggi FDR maka semakin tinggi dana yang disalurkan ke dana pihak ketiga. Dengan penyaluran dana pihak ketiga yang besar maka semakin besar ROA bank. Dalam penelitian Ponco (2008), Dhian (2012) menunjukkan bahwa FDR berpengaruh positif dan signifikan terhadap ROA. Sedangkan dalam penelitian Lyla (2011), menunjukan hasil bahwa FDR berpengaruh negatif dan tidak signifikan terhadap ROA. Dengan adanya research gap dari penelitian, Ponco (2008) Dhian (2012) dan Lyla (2011), maka perlu dilakukan penelitian lanjutan pengaruh FDR terhadap ROA.

Pada fenomena tersebut menjadikan peneliti tertarik untuk menganalisis lebih lanjut terkait permasalahan yang ada pada perbankan Syariah khususnya pada PT Bank Muamalat Indonesia. Menurut Ummah dan Suprapto (2015) PT Bank Muamalat Indonesia adalah bank syariah pertama di Indonesia yang didirikan pada tahun 1991 dan memulai kegiatan operasionalnya pada bulan Mei 1992. PT Bank Muamalat Indonesia merupakan bank pertama di Indonesia yang kegiatannya berdasarkan prinsip-prinsip islam. Bank Muamalat sebagai pioneer bank islam di Indonesia merupakan pelopor atas pendirian bank-bank Islam yang lain. Bank Muamalat Indonesia pada awal pendiriannya belum mendapat perhatian yang maksimal dalam industri perbankan nasional (Muhammad, 2011:26).

Alasan peneliti memilih Bank Muamalatn Indonesia dan periode penelitian tahun 2012-2016 karena pada aset dan laba bersih Bank Muamalat 
Wibowo, et al/Jurnal Ekonomi Syariah Teori dan Terapan Vol. 6 No. 3 Maret 2019: 477-488; PENGARUH PEMBIAYAAN NON BAGI HASIL DAN FINANCING TO DEPOSIT RATIO (FDR) TERHADAP PROFITABILITAS PADA PT BANK MUAMALAT INDONESIA TAHUN 2012-2016

$\begin{array}{rrr}\text { cenderung } & \text { fluktuatif } & \text { dibandingkan } \\ \text { dengan } & \text { bank } & \text { syariah }\end{array}$ lainnya.Berdasarkanpenjelasantersebut, makadalampenelitianinipenulisakanmem bahasmengenai "PengaruhPembiayaan Non BagiHasildanFinancing to Deposit Ratio (FDR) TerhadapProfitabilitasPada PT Bank Muamalat Indonesia Tahun 20122016."

\section{Rumusan Masalah}

1. Apakah komposisi pembiayaanNatural Certainty Contracts (NCC) secara parsial berpengaruh terhadap Return On Asset (ROA) pada PT Bank Muamalat Indonesia?

2. Apakah Financing to Deposit Ratio (FDR) secara parsial berpengaruh terhadap Retrun On Assets (ROA) pada PT Bank Muamalat Indnesia?

3. Apakah komposisi pembiayaanNatural Certainty Contracts (NCC)dan Financing to Deposit Ratio (FDR) secara simultan berpengaruh terhadap Return On Assets (ROA)pada PT Bank Muamalat Indonesia?

II. LANDASAN TEORI

\section{Definisi Bank Syariah}

Menurut Rivai (2007:768) Bank syariahmerupakan bank yang lebih menekankanpada prinsip bagi hasil yang merupakanlandasan utama dalam semua operasinya, baik dalam pengerahan dananya maupun dalam penyaluran dananya.

\section{Pembiayaan Bank Syariah}

Pembiayaan dalam perbankan syariah menurut ketentuan Bank Indonesia adalah penanaman dana Bank Syariah baik dalam rupiah maupun valuta asing dalam bentuk pembiayaan, piutang, qardh, surat berharga syariah, penempatan, penyertaan modal sementara, komitmen dan kontinjensi pada rekening administratif serta sertifikat wadiah Bank Indonesia (Muhammad, 2011:196).

\section{Pembiayaan Bank Syariah Berbasis Akad Natural Certainty Contracts (NCC)}

Dalam perbankan syariah terdapat dua jenis kontrak pembiayaan bila dibedakan dari sifat alami pengembalian atas kontrak -kontrak tersebut. Disinilah muncul istilah Natural Certainty Contracts atau pembiayaan non bagi hasil dan Natural Uncertainty Contracts atau pembiayaan bagi hasil. NCC adalah kontrak atau akad bisnis yang mana terdapat kepastian pembayaran dalam jumlah dan waktu. Pembiayaan yang termasuk dalam NCC adalah pembiayaan dengan akad murabahah, ijarah, salam, istishna' (Hidayat, 2011:51).

Menurut Syafi'i dalam Fahrul, et al., (2012) pembiayaan murabahah adalah adalah jual beli barang pada harga asal dengan tambahan keuntungan yang disepakati. Praktek pembiayaan murabahah dalam perbankan syariah diperbolehkan dalam Islam. Hal ini dijelaskan pada firman Allah SWT dalam QS An-Nisa ayat 29: 


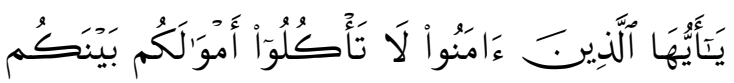

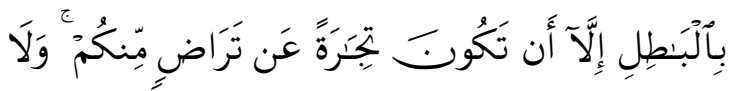

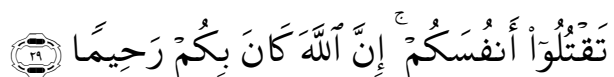

Yā ayyuhaal-lazīna āmanū lā ta`kulū amwālakum bainakum bil-bātili illa an takūna tijāratan'an tarādim minkum, wa lā taqtulū anfusakum, innallāha kāna bikum rahimā(n).

Artinya: "Wahai orang-orang yang beriman, janagnlah kalian memakan harta-harta kalian di antara kalian dengan cara yang batil, kecuali dengan perdagangan yang kalian saling ridha. Dan janganlah kalian membunuh diri-diri kalian, sesungguhnya Allah itu Maha Kasih Sayang kepada kalian" (Departemen Agama Rl, 2002:84).

Menurut Fatwa DSN No. 06/DSNMUI/IV/2000 Istishna adalah jual beli dalam bentuk pemesanan pembuatan barang tertentu dengan kriteria dan persyaratan tertentu yang disepakati antara pemesan dan penjual. Landasan syariah pembiayaan istishna' yaitu surat $\mathrm{Al}$ Baqarah ayat 282 yaitu:

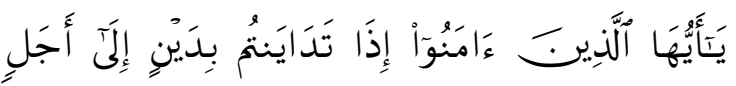

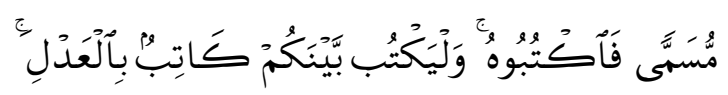
Yā ayyuhal-lażina aamanū iżaa tadaayantum ilā ajalim-musamma faktubuuh walyaktub-bainakum kaatibum-bil adl......

Artinya: "Hai orang-orang yang beriman, apabila kamu bermu'amalah tidak secara tunai untuk waktu yang ditentukan, hendaklah kamu menuliskannya........" (QS. Al-Baqarah:282).

ljarah adalah akad pemindahan hak guna atas barang dan jasa melalui pembayaran upah sewa tanpa diikuti dengan pemindahan barang itu sendiri (Ismail, 2011:160). Landasan syariah terkait pembiayaan ijarah dijelaskan dalam surat Al Baqarah ayat 233:

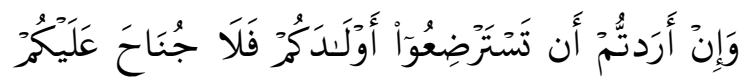

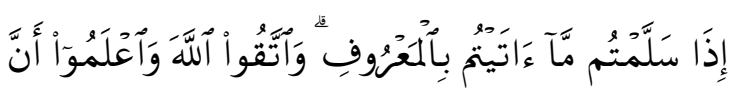
آللَّهَ بمَا تَعْمَلُونَ بَصِيرِ Wa in arratum an tastardi'ú aulādakum falā junāha 'alaikum izā sallamtum mā ātaitum bilma'rūfi, Wattaqullāha wa'lamū annallāhu bimā ta'malūna bașirun. (Departemen Agama Rl, 2002:38).

Artinya: "Dan jika kamu ingin anakmu disusukan oleh orang lain, Maka tidak ada dosa bagimu apabila kamu memberikan pembayaran menurut yang patut. bertakwalah kamu kepada Allah dan ketahuilah bahwa Allah Maha melihat apa yang kamu kerjakan."

\section{Financing to Deposit Ratio (FDR)}

Sholihin (2010:277) mengatakan bahwa Financing to Deposit Ratio (FDR) adalah perbandingan pembiayaan yang diberikan oleh bank dengan dana pihak ketiga yang berhasil dikerahkan oleh bank. Semakin tinggi FDR maka penyaluran dana (pembiayaan) oleh bank akan meningkat (Munandar, 2009).

Rasio yang tinggi menunjukkan bahwa bank meminjamkan seluruh dananya atau relatif tidak likuid. 
Wibowo, et al/Jurnal Ekonomi Syariah Teori dan Terapan Vol. 6 No. 3 Maret 2019: 477-488; PENGARUH PEMBIAYAAN NON BAGI HASIL DAN FINANCING TO DEPOSIT RATIO (FDR) TERHADAP PROFITABILITAS PADA PT BANK MUAMALAT INDONESIA TAHUN 2012-2016

Sebaliknya rasio yang rendah menunjukkan bank yang likuid dengan kelebihan kapasitas dana yang siap untuk dipinjamkan (Dendawijaya, 2005:116). Menurut (Muhammad, 2004:159) rumus untuk mengukur tingkat FDR yaitu Volume Pembiayaan/DPKx 100\%

\section{Return On Assets (ROA)}

Menurut Tandelilin (2001) Return On Assets menggambarkan sejauh mana kemampuan aset-aset yang dimiliki perusahaan bias menghasilkan laba. Sehingga rasio ROA dapat dirumuskan yaitu:

ROA $=$ Laba setelah pajak/Total Aset $\mathrm{x}$ $100 \%$

\section{Hubungan Antar Variabel}

Hubungan komposisi pembiayaan NCC terhadap ROA. Menurut Riyadi dan Yulianto (2014), tinggi rendahnya nilai pembiayaan NCC akan berpengaruh terhadap return yang dihasilkan, sebab dengan adanya pembiayaan NCC yang disalurkan kepada nasabah, bank mengharapkan akan mendapatkan return dan margin keuntungan atas pembiayaan NCC yang diberikan kepada nasabah yang kemudian margin keuntungan tersebut menjadi laba bank syariah. Arah hubungan yang timbul antara pembiayaan NCC terhadap ROA adalah positif karena apabila pembiayaan NCC yang disalurkan meningkat maka akan meningkatkan ROA yang didapat oleh bank syariah.

Hubungan FDR terhadap ROA. Menurut Medina dan Rina (2018), jika FDR semakin tinggi maka memberikan indikasi semakin rendahnya kemampuan likuiditas bank yang bersangkutan. Berkurangnya tingkat likuiditas dapat memberikan dampak terhadap naiknya profitabilitas. Sebaliknya semakin rendah FDR menunjukkan kurangnya efektifitas bank dalam menyalurkan kredit yang akan mempengaruhi profitabilitas bank tersebut (Medina dan Rina, 2018).

Jika FDR bank berada pada standar yang ditetapkan oleh Bank Indonesia, maka laba yang diperoleh bank tersebut akan meningkat dengan asumsi bank menyalurkan pembiayaannya dengan efektif. Efektifnya penyaluran pembiayaan yang dilakukan bank akan menghasilkan pendapatan berupa nisbah bagi hasil, margin/mark up, maupun pendapatan sewa yang menyebabkan laba yang diperoleh bank meningkat. Dengan meningkatnya laba, maka ROA juga akan meningkat, karena laba merupakan komponen yang membentuk ROA (Mahardian, 2008).

\section{Hipotesis}

Berdasarkan teori dan konsep yang dijelaskan dalam rumusan masalah, tujuan, dan landasan teori, maka dalam penelitian ini dapat dirumuskan hipotesis sebagai berikut:

$\mathrm{H} \mathrm{l}=$ Komposisi pembiayaan NCC berpengaruh positif signifikan terhadap ROA.

$H 2=F D R$ berpengaruh positif signifikan terhadapROA. 
Wibowo, et al/Jurnal Ekonomi Syariah Teori dan Terapan Vol. 6 No. 3 Maret 2019: 477-488; PENGARUH PEMBIAYAAN NON BAGI HASIL DAN FINANCING TO DEPOSIT RATIO (FDR) TERHADAP PROFITABILITAS PADA PT BANK MUAMALAT INDONESIA TAHUN 2012-2016

H3=Komposisi pembiayaan NCC dan FDR berpengaruh positif signifikan terhadap ROA.

\section{METODE PENELITIAN}

\section{Pendekatan Penelitian}

Pendekatan yang digunakan dalam penelitian ini adalah pendekatan kuantitatif. Teknik analisis yang digunakan dalam penelitian ini adalah regresi linear berganda dengan menggunakan program SPSS versi 22.

\section{Jenis dan Sumber Data}

Jenis dan Sumber data yang digunakan dalam penelitian ini adalah data sekunder yang diperoleh dari laporan kevangan PT Bank Muamalat Indonesia yang dipublikasikan oleh Otoritas Jasa Keuangan yaitu www.ojk.go.id dan Bank Indonesia yaitu www.bi.go.id.

$$
\text { Data dalam penelitian ini }
$$
menggunakan data sekunder berupa data time series. Data-data yang diambil adalah data dari seluruh Bank PT Bank Muamalat Indonesia. Periode yang diambil dalam penelitian ini adalah bulan Januari 2012 sampai dengan bulan Desember 2016 dengan menggunakan laporan keuangan bulanan Perbankan Syariah di Indonesia.

$$
\text { Populasi dalam penelitian ini }
$$

adalah PT Bank Muamalat Indonesia. Sampel dalam penelitian ini diambil dengan sampling jenuh.Menurut Sugiyono (2001:61)sampling jenuh adalah teknik penentuan sampel bila semua anggota populasi digunakan sebagai sampel. Istilah lain sampel jenuh adalah sensus, dimana semua anggota populasi dijadikan sampel. Sampel dalam penelitian ini adalah semua PT Bank Muamalat yang ada di Indonesia yang diambil 60 bulan terakhir yaitu periode Januari 2012 sampai dengan periode Desember 2016.

\section{Prosedur Pengumpulan Data}

Pengumpulan data dilakukan melalui studi kepustakaan dengan metode dokumenter yang didapatkan dari berbagi sumber, yaitu dari ruang baca fakultas ekonomi dan bisnis Universitas Airlangga, perpustakan kampus B universitas airlangga, dan dari internet.

\section{Teknis Analisis Data}

Teknik analisis yang dipakai guna menjawab permasalahan dan membuktikan hipotesis yang diajukan oleh peneliti sebagai berikut:

1. Uji Normalitas

Ghozali (2013:160) menyatakan uji normalitas digunakan untuk menguji apakah dalam model regresi variabel pengganggu atau residual memiliki distribusi normal. Seperti diketahui bahwa uji † dan $F$ mengasumsikan bahwa nilai residual mengikuti distribusi normal. Kalau asumsi ini dilanggar maka uji statistik menjadi tidak valid. Normalitas dapat dideteksi dengan melihat penyebaran data pada sumbu diagonal dan grafik atau dengan melihat hasil uji statistiknya.

2. Uji Multikolinieritas

Uji multikolinieritas digunakan untuk menguji apakah model regresi ditemukan adanya korelasi antar masing-masing variabel independen atau bebas. Salah 
Wibowo, et al/Jurnal Ekonomi Syariah Teori dan Terapan Vol. 6 No. 3 Maret 2019: 477-488; PENGARUH PEMBIAYAAN NON BAGI HASIL DAN FINANCING TO DEPOSIT RATIO (FDR) TERHADAP PROFITABILITAS PADA PT BANK MUAMALAT INDONESIA TAHUN 2012-2016

satu cara mengukur multikolinieritas adalah dengan cara variance inflation factor (VIF) Tolerance.

3. Uji Heteroskedastisitas Setiawan dan Kusrini (2010:103) menerangkan bahwa salah satu asumsi regresi linier berganda adalah homogenitas variansi dari error (homoskedastisitas). Homoskedastisitas adalah variansi dari error yang bersifat konstanta (tetap). Heteroskedatisitas merupakan kebalikan dari homoskedastisitas dimana kondisi variansi dari error bersifat tidak tetap atau tidak identik. Heteroskedastisitas pada umumnya terjadi pada penelitian yang menggunakan model data cross section dan time series.

4. Uji Autokorelasi

$$
\text { Widarjono (2010:98) menjelaskan }
$$

uji autokorelasi bertujuan untuk mengetahui apakah dalam suatu model analisis regresi linier berganda terdapat korelasi antara kesalahan pengganggu pada periode $\dagger$ dengan kesalahan pada periode $t-1$ atau periode sebelumnya. Autolorelasi merupakan korelasi antara variabel gangguan satu observasi dengan variabel gangguan observasi lainnya.

5. Analisis Regresi Linier Berganda

Analisis regresi linier berganda yang digunakan dalam penelitian ini bertujuan untuk mengetahui keakuratan hubungan antara variabel dependen yaitu ROA dengan variabel independennya yaitu komposisi pembiayaan NCC dan FDR.
6. Analisis Koefisien Determinasi (Rsquare)

Firdaus (2004:77) menjelaskan koefisien determinasi digunakan untuk mengetahui berapa besarnya persentase sumbangan varibel independen terhadap variasi variabel dependen secara bersama-sama.

7. Uji Hipotesis

Uji hipotesis bertujuan untuk menguji hipotesis yang telah dirumuskan dalam penelitian. Uji hipotesis ini dapat diuji baik secara simultan maupun parsial.

8. Uji $F$

Uji F atau yang disebut uji simultan digunakan untuk menguji signifikansi pengaruh seluruh variabel independen secara bersama-sama terhadap variabel dependennya (Retno, 2017).

9. Uji $\dagger$

Uji ini dimaksudkan untuk mengetahui tingkat signifikansi pengaruh masing-masing variabel independen terhadap variabel dependen dengan asumsi variabel independen yang lain tidak berubah. Uji † juga disebut sebagai uji parsial dimana digunakan untuk menguji signifikansi pengaruh seluruh variabel independen secara sendiri-sendiri (parsial) terhadap variabel dependen (Retno, 2017).

\section{HASIL DAN PEMBAHASAN}

\section{Analisis Regresi Linear Berganda}

1. Konstanta sebesar 0.838 menunjukkan apabila komposisi pembiayaan NCC dan FDR besarnya nol atau konstan, maka nilai ROA sebesar 0.838 . 
Wibowo, et al/Jurnal Ekonomi Syariah Teori dan Terapan Vol. 6 No. 3 Maret 2019: 477-488; PENGARUH PEMBIAYAAN NON BAGI HASIL DAN FINANCING TO DEPOSIT RATIO (FDR) TERHADAP PROFITABILITAS PADA PT BANK MUAMALAT INDONESIA TAHUN 2012-2016

2. Nilai koefisien regresi variabel komposisi pembiayaan NCC sebesar 2.042 dimana nilai ini memiliki tanda positif. Hal ini menunjukkan hubungan yang searah, apabila komposisi pembiayaan NCC mengalami peningkatan sebesar 1 satuan dan variabel independen lainnya dianggap konstan, maka ROA akan mengalami peningkatan sebesar 2.042 satuan.

3. Nilai koefisien regresi variable FDR sebesar $-0,015$ dimana nilai ini memiliki tanda negatif. Hal ini menunjukkan hubungan yang berbanding terbalik, apabila FDR mengalami peningkatan sebesar 1 satuan dan variabel independen lainnya dianggap konstan, maka ROA akan mengalami penurunan sebesar 0,015 satuan.

\section{Analisis Koefisien Determinasi (R-square)}

Hasil uji nilai R2 sebesar 0.194 atau $19.4 \%$, dengan kata lain $19.4 \%$ ROA dipengaruhi oleh variabel komposisi pembiayaan NCC dan FDR, sedangkan sisanya sebesar $80.6 \%$ dipengaruhi oleh faktor- faktor lain diluar model penelitian.

Pengaruh Komposisi PembiayaanNCC terhadap ROA.

Uji $F$

Signifikansi dari hasil uji $F$ sebesar 0.002 dimana nilai ini lebih kecil dari a (0.002<0,05 ), sehingga HO ditolak. Berdasarkan hasil pengolahan data dapat disimpulkan bahwa komposisi pembiayaan NCC dan FDR secara simultan berpengaruh signifikan terhadap ROA pada PT Bank Muamalat Indonesia.
Pengaruh masing-masing variabel independen terhadap variabel dependen secara parsial dapat dijelaskan sebagai berikut:

1. Variabel komposisi pembiayaan NCC memiliki nilai signifikansi lebih besar dari a (0.278 > 0.05), sehingga HO diterima. Berdasarkan hasil uji † dapat disimpulkan bahwa secara parsial komposisi pembiayaan NCC berpengaruh tidak signifikan terhadap ROA.

2. Variabel FDR memiliki nilai signifikansi lebih kecil dari a $(0.001<0.05)$, sehingga HO ditolak. Berdasarkan hasil uji † dapat disimpulkan bahwa secara parsial FDR berpengaruh signifikan terhadap ROA.

\section{Pengaruh Komposisi Pembiayaan NCC secara Parsial Terhadap ROA}

Pengaruh komposisi pembiayaan NCC terhadap ROA secara parsial dapat dilihat pada nilai signifikansi yang didapatkan dari pengujian hasil uji t. Berdasarkan hasil pengolahan data uji $\dagger$ diketahui bahwa signifikansi pada komposisi pembiayaan NCC sebesar 0.278 dimana nilai ini lebih besar dari a 0.278 > 0.05), sehingga HO diterima. Hal ini menunjukkan bahwa komposisi pembiayaan NCC secara parsial tidak signifikan terhadap ROA.

Hal ini sesuai dengan prinsip "high risk, high return" artinya semakin tinggi resiko, semakin besar pula jumlah keuntungan yang mungkin diperoleh, sehingga resiko pembiayaan NUC yang besar semakin besar pula jumlah keuntungan yang mungkin diperoleh pada pembiayaan NUC. Sebaliknya 
Wibowo, et al/Jurnal Ekonomi Syariah Teori dan Terapan Vol. 6 No. 3 Maret 2019: 477-488; PENGARUH PEMBIAYAAN NON BAGI HASIL DAN FINANCING TO DEPOSIT RATIO (FDR) TERHADAP PROFITABILITAS PADA PT BANK MUAMALAT INDONESIA TAHUN 2012-2016

sesuai dengan prinsip "low risk, low return" artinya semakin rendah resiko, semakin rendah pula jumlah keuntungan yang mungkin diperoleh, sehingga resiko pembiayaan NCC yang kecil, semakin kecil pula jumlah keuntungan yang mungkin diperoleh.

Peristiwa ini didukung dengan perkembangan dari jumlah pembiayaan NCC yang disalurkan Bank Muamalat Indonesia setiap bulannya mulai dari Januari 2012 hingga Desember 2016 relatif meningkat pesat. Namun ROA bank syariah setiap bulannya mengalami peningkatan yang relatif stabil atau hanya beberapa persen, bahkan terkadang mengalami penurunan walaupun NCC mengalami kenaikan setiap periodenya. Hal ini menunjukkan bahwa pengaruh NCC secara parsial tidak nyata.

\section{Pengaruh FDR secara Parsial terhadap ROA}

Pengaruh FDR terhadap ROA secara parsial dapat dilihat pada nilai signifikansi yang didapatkan dari pengujian hasil uji t. Berdasarkan hasil pengolahan data uji † diketahui bahwa signifikansi pada FDR sebesar 0.001 dimana nilai ini lebih kecil dari a $0.001<$ 0.05), sehingga $\mathrm{HO}$ ditolak. Hal ini menunjukkan bahwa FDR secara parsial berpengaruh signifikan terhadap ROA. Berdasarkan persamaan regresi linier berganda dapat diketahui bahwa nilai FDR memiliki hubungan negatif terhadap ROA dimana koefisien dari nilai FDR sebesar -0.015 , sehingga dapat dikatakan bahwa apabila FDR mengalami peningkatan, maka akan menyebabkan ROA mengalami penurunan.

Menurut Aprilia (2016), semakin besar penyaluran dana dalam bentuk pembiayaan dibandingkan dengan deposit atau simpanan masyarakat pada suatu bank membawa konsekuensi semakin besarnya risiko yang ditanggung oleh bank yang bersangkutan. Apabila pembiayaan yang disalurkan mengalami kegagalan atau bermasalah, bank akan mengalami kesulitan untuk mengembalikan dana yang dititipkan oleh masyarakat. Selama tahun pengamatan, kenaikan FDR ini diikuti dengan kenaikan jumlah pembiayaan daripada dana pihak ketiga sehingga bank menanggung risiko tidak bias mengembalikan dana pihak ketiga yang dihimpunolehmasyarakat. Sehinggaketika FDR meningkat, rasio profitabilitas yang diukur dengan Return On Asset Bank Muamalat Indonesia menurun. FDR berpengaruh negative terhadap ROA dikarenakan bank syariah cenderung menjaga tingkat likuiditasnya pada titik aman. Juga dimungkinkan karena peningkatan dalam pembiayaan atau penarikan dana yang besar oleh masyarakat yang berdampak pada semakin rendahnya likuiditas bank tersebut. Hal ini akan berdampak pada kepercayaan masyarakat dan bias menyebabkan penurunan profitabilitas yang ditandai dengan menurunnya ROA (Aprilia, 2016).

Pengaruh Komposisi Pembiayaan NCC dan FDR secara simultan terhadap ROA 
Wibowo, et al/Jurnal Ekonomi Syariah Teori dan Terapan Vol. 6 No. 3 Maret 2019: 477-488; PENGARUH PEMBIAYAAN NON BAGI HASIL DAN FINANCING TO DEPOSIT RATIO (FDR) TERHADAP PROFITABILITAS PADA PT BANK MUAMALAT INDONESIA TAHUN 2012-2016

Pengaruh komposisi pembiayaan NCC dan FDR terhadap ROA secara simultan dapat dilihat pada nilai signifikansi yang didapatkan dari pengujian hasil uji F. Berdasarkan hasil pengolahan data uji $\mathrm{F}$ diketahui bahwa signifikansi pada komposisi pembiayaan NCC dan FDR sebesar 0.002 dimana nilai ini lebih kecil dari a $(0.002<0.05)$, sehingga HO ditolak. Hal ini menunjukkan bahwa komposisi pembiayaan NCC dan FDR secara simultan berpengaruh signifikan terhadap ROA. Hasil penelitian ini sejalan dengan penelitian Slamet dan Agung (2014) yang menyatakan bahwa secara simultan pembiayaan bagihasil, pembiayaan jual beli, FDR dan NPF berpengaruh signifikan terhadap profitabilitas dan penelitian Ernawati (2014) yang menyatakan bahwas ecara simultan NUC, NCC, FDR dan NPF memiliki pengaruh terhadap profitabilitas perbankansyariah di Indonesia.

ROA merupakan salah satu indicator utama yang digunakan oleh perbankan dalam mengukur kinerja keuangannya. Kasmir (2008:199) menjelaskan bahwa ROA menunjukkan hasil (return) atasjumlahaktiva yang digunakan dalam perusahaan. Semakin tinggi perolehan ROA maka menunjukkan semakin baik kinerja BPRS. Hal ini disebabkan oleh semakin tingginya tingkat keuntungan yang diperoleh bank. Semakinbaikmanajemen bank dalam menghasilkan keuntungan, maka akan menunjukkan keberhasilan bank dalam menjalankan kegiatannya. Anastasia dan
Septiarini (2015) menyatakan apabila rasio keuangan suatu bank baik maka hal ini juga mencerminkan kinerja yang baik pula pada bank tersebut. Kinerja yang baik salah satunya ditunjukkan dengan tingginya ROA.

\section{SIMPULAN}

Berdasarkan hasil penelitian dapat diambil beberapa kesimpulan sebagai berikut:

1. Berdasarkan hasil statistic uji $\dagger$ (parsial) variable komposisi pembiayaan NCC terhadap ROA memiliki nilai signifikansi sebesar 0.278 , nilais ignifikansi variable komposisi pembiayaan NCC menunjukkannilai di atast ingkat signifikan yang ditetapkan sebesar $5 \%$ $(a=0.05)$, sehingga dapat disimpulkan komposisi pembiayaan NCC secara parsial tidak signifikan terhadap Return On Assets (ROA) pada PT Bank Muamalat Indonesia periode 20122016.

2. Berdasarkan hasil statistic uji $\dagger$ (parsial) variabel FDR terhadap ROA memiliki nilai signifikansi sebesar -0.001 , nilai signifikansi variabel FDR menunjukkan nilai di bawah tingkat signifikan yang ditetapkansebesar 5\% (a = 0.05) sehingga dapat disimpulkan bahwa FDR secara parsial berpengaruh significant erhadap Return On Assets (ROA). Sedangkan nilai beta pada variabel FDR sebesar -0,015 yang menunjukkan bahwa FDR secara parsial berpengaruh negative terhadap ROA. Hasil yang negative menunjukkan bahwa meningkatnya 
FDR akan berdampak pada penurunan ROA pada PT Bank Muamalat Indonesia periode 2012-2016.

3. Berdasarkan hasil statistic uji $F$ (simultan), variable komposisi pembiayaandan FDR terhadap ROA memiliki nilai signifikansi sebesar 0.002, nilai signifikansi variable ini menunjukkan nilai di bawah tingkat signifikan yang ditetapkan sebesar $5 \%$ $(a=0.05)$, sehingga dapat disimpulkan bahwa komposisi pembiayaan NCC dan FDR berpengaruh signifikan terhadap Return On Assets (ROA) pada PT Bank Muamalat Indonesia periode 2012-2016.

\section{DAFTAR PUSTAKA}

Al Qur'an danTerjemahannya. 2002. Jakarta: Kementrian Agama RI.

Augusty, Ferdinand. 2006. Metode Penelitian Manajemen: Pedoman Penelitian untuk skripsi, Tesis dan Disertasi IImu Manajemen. Semarang: Universitas Diponegoro.

Ardianto, F. D. 2014. Pengaruh Pembiayaan Dan Rasio Non Performing financing (NPF) Terhadap Asset Turn Over (ATO) Bank Umum Syariah Nasional Di Indonesia. Jurnal Ekonomi dan Bisnis.

Afif, Zaim Nur, 2014. Pengaruh Pembiayaan Murabahah Terhadap Laba Melalui Variabel Intervening Pembiayaan Bermasalah Bank Umum Syariah di Indonesia Periode 2009-2013.
Skripsi. Surabaya: Universitas Airlangga.

Dendawijaya, Lukman. 2009. Manajemen Perbankan. Ghalia Indonesia, Jakarta.

Dewi dan Yusak. 2017. Pengaruh Pembiayaan Murabahah, istishna, Mudharabah, dan Musyarakah Terhadap Profitabilitas (Studi Pada Bank Syariah di Indonesia Periode Maret 2015-Agustus 2016). Accounting and Management Journal, Vol 1, No 1, July 2017.

Fahrul, F., Arfan dkk. 2012. Pengaruh Tingkat Risiko Pembiayaan Musyarakah Dan Pembiayaan Murabahah Terhadap Tingkat Profitabilitas Bank Syariah (Studi Pada Bank Aceh Syariah Cabang Banda Aceh). Jurnal Akuntansi Pascasarjana Universitas Syiah Kuala, Vol. 2, No. 1.Account

Fatmawati Ima dkk, 2016. Pengaruh Pembiayaan Murabahah, Mudharabah, Musyarakah dan ljarah terhadap Laba Bersih Bank Umum Syariah di Indonesia. Skripsi.Jember:

FakultasEkonomiUniversitasJember. Ningsih, Hartini. 2008. AnalisisPengaruh Total Asset Turn Over dan BOPO TerhadapProfitabilitas Bank Syariah (StudiKasusPada Bank BTN Kantor CabangSyariah Jakarta). Skripsi. Jakarta: UIN SyarifHidayatullah.

Heri Sudarsono (2008), Bank \& Lembaga Keuangan Syari'ah. Yogyakarta: Ekonisia. Cetakan ke-2. 
Hidayah, Liza Nur. 2013. Pengaruh Pembiayaan Natural Uncertainty Contracts (NUC) dan Natural Certainty Contracts (NCC) Terhadap Profitabilitas Bank Umum Syariah Periode 2008-2012. Skripsi. Malang: UniversitasNegeriMaulana Malik Ibrahim.

Hidayat, Taufik. 2011.

BukuPintarlnvestasiSyariah. Jakarta: Mediakita.

Ismail. 2011. Perbankan Syariah. Jakarta: Kencana.

Kasmir. 2008. Analisis Laporan Keuangan. Jakarta: PT. Raja Grafindo Persada. Karim, A. A. 2011 . Bank Islam Analisis Fiqih dan Kevangan. Jakarta: PT Raja Grafindo Persada.

Tahun 2011-2013. Skripsi. Surakarta: Universitas Muhammadiyah Surakarta.

Muhammad. 2004. Manajaemen Dana Bank Syariah. Edisi Pertama. Ekonisia: Yogyakarta.

Muhammad. 2011. Manajemen Bank Syariah. Yogyakarta:UPP STIM YKPN.

Muhammad. 2012.

TeknikPerhitunganBagiHasil Dan Pricing Di Bank Syariah. Yogyakarta: UII Press.

Munandar, Eris. 2009. Pengaruh Dana Pihak Ketiga, Loan to Deposit Ratio dan Return On Asset Terhadap
Pembiayaan pada Bank Syariah Mandiri. Universitas Islam Negeri Sunan Kalijaga: Yogyakarta.

Prastowo, DwidanRifkaJuliaty. 2010. AnalisisLaporanKeuangan :KonsepdanAplikasi (Edisi 3). Yogyakarta: UPP STIM YKPN.

Rivai, Veithzal. 2007. Bank and Financial Institute Management. PT Raja GrafindoPersada: Jakarta. 